\title{
Experimental fossilisation of viruses from extremophilic Archaea
}

\author{
F. Orange ${ }^{1,2}$, A. Chabin ${ }^{1}$, A. Gorlas ${ }^{3}$, S. Lucas-Staat ${ }^{4}$, C. Geslin ${ }^{3}$, M. Le Romancer ${ }^{3}$, D. Prangishvili ${ }^{4}$, P. Forterre ${ }^{4}$, \\ and $\mathbf{F}$. Westall ${ }^{1,2}$ \\ ${ }^{1}$ Centre de Biophysique Moléculaire, UPR4301, CNRS, Rue Charles Sadron, 45071 Orléans Cedex 2, France \\ ${ }^{2}$ Observatoire des Sciences de l'Univers en région Centre, UMS3116, 1A Rue de la Férollerie, 45071 Orléans Cedex 2, France \\ ${ }^{3}$ Université de Bretagne Occidentale, UMR 6539, CNRS - Institut Universitaire Européen de la Mer, \\ Technopôle Brest-Iroise, Rue Dumont d'Urville, 29280 Plouzané, France \\ ${ }^{4}$ Molecular Biology of the Gene in Extremophiles Unit, Institut Pasteur, 25 rue du Docteur Roux, \\ 75724 Paris Cedex 15, France
}

Received: 16 February 2011 - Published in Biogeosciences Discuss.: 4 March 2011

Revised: 20 May 2011 - Accepted: 26 May 2011 - Published: 9 June 2011

\begin{abstract}
The role of viruses at different stages of the origin of life has recently been reconsidered. It appears that viruses may have accompanied the earliest forms of life, allowing the transition from an RNA to a DNA world and possibly being involved in the shaping of tree of life in the three domains that we know presently. In addition, a large variety of viruses has been recently identified in extreme environments, hosted by extremophilic microorganisms, in ecosystems considered as analogues to those of the early Earth. Traces of life on the early Earth were preserved by the precipitation of silica on the organic structures. We present the results of the first experimental fossilisation by silica of viruses from extremophilic Archaea (SIRV2 - Sulfolobus islandicus rod-shaped virus 2, TPV1 - Thermococcus prieurii virus 1, and PAV1 - Pyrococcus abyssi virus 1). Our results confirm that viruses can be fossilised, with silica precipitating on the different viral structures (proteins, envelope) over several months in a manner similar to that of other experimentally and naturally fossilised microorganisms. This study thus suggests that viral remains or traces could be preserved in the rock record although their identification may be challenging due to the small size of the viral particles.
\end{abstract}

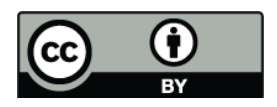

Correspondence to: F. Orange (francois.orange@gmail.com)

\section{Introduction}

The role of viruses in the early evolution of life has recently been reevaluated. Viruses were long considered as non-living by-products of cellular activity and thus unable to have played a role in the origin and evolution of their hosts. Over the last decade, however, our views on the origin and nature of viruses have dramatically changed. Structural similarities between viruses infecting phylogenetically distant hosts suggest that viruses were already active at the time of the Last Universal Common Ancestor (LUCA) and probably before (Bamford et al., 2005; Koonin and Dolja, 2006; Krupovic and Bamford, 2008). Comparative genomics has revealed that most genes encoded by viruses have no cellular homologues, testifying to the creativity of virocells (Forterre, 2011) in inventing new proteins. Several theories and discoveries have been made regarding the ancient nature of viruses and their possible key roles in the early evolution of life and in the origin of modern cells (Forterre, 2002; Bamford, 2003; Koonin et al., 2006; for recent reviews and alternative viewpoints, see Moreira and López-García, 2009 and Forterre and Prangishvili, 2009a, b). For instance, viruses have been evoked to explain the origin of DNA cells. Starting from an RNA world (cells with RNA genomes), DNA could have appeared in viruses (DNA viruses) and then have been transferred to cells (Forterre, 2002). One hypothesis also suggests that interactions between DNA viruses and RNA cells (fusion, gene transfers) could have resulted in the formation of the three domains (Eukaryotes, Bacteria, Archaea) (Forterre, 2006). Finally, the discovery of Mimivirus, a giant DNA

Published by Copernicus Publications on behalf of the European Geosciences Union. 
virus infecting Amoeba (La Scola et al., 2003), permits a virus genome to be included in the universal tree of life. This suggests that giant viruses could be intermediates between cells and previously known viruses and could form a new domain of life (Raoult et al., 2004).

A major development in recent years in virology has been the discovery of very diverse new viruses in extreme environments. Such environments are particularly interesting as they are often considered as analogues of the environments on the early Earth in which life could have originated. Microorganisms found in these environments are also considered to be possible analogues to the earliest forms of life on Earth and possibly on Mars (Nisbet and Sleep, 2001; Konhauser et al., 2003). Recognition of the ancient nature of viruses suggests that early life forms could have hosted viruses. The study of viruses of extremophilic microorganisms is a relatively recent field. Nevertheless, it has already allowed the identification of several thousands of viruses having different morphologies and characteristics, and also of new virus families (see review in Le Romancer et al., 2007). Viruses have been identified in all known extreme environments: hypersaline (Oren et al., 1997; Dyall-Smith et al., 2003; Pagaling et al., 2007; Sime-Ngando et al., 2010), alkaline lakes (Jiang et al., 2004), deserts (Prigent et al., 2005), polar regions (Maranger et al., 1994; Kepner et al., 1998; Borriss et al., 2003; Gowing, 2003), acid mine drainages (Kyle et al., 2008a), deep subsurface rocks (Bird et al., 2001; Kyle et al., 2008b), and in hydrothermal environments. The search for new viruses in the latter environment has been especially fruitful, following the pioneering work of Wolfram Zillig on the viruses of hyperthermophilic Archaea (Martin et al., 1984; Rice et al., 2001; Rachel et al., 2002). Many new viral families that infect hyperthermophilic Archaea in terrestrial and marine hot springs have been identified (Geslin et al., 2003b; Ortmann and Suttle, 2005; Geslin et al., 2005; Prangishvili et al., 2006a; Ortmann et al., 2006; Le Romancer et al., 2007). Although these viruses all have double-stranded DNA genomes, they produce virions with very diverse morphologies (e.g. rod-shaped, filamentous, spindle-shaped, ellipsoid, head and tail) and most proteins encoded in their genomes have no homologues, except sometimes in other viral lineages (Prangishvili et al, 2006b).

Although structural and comparative genomics point to the antiquity of viruses, their fossil remains have yet to be detected in the rock record. Although challenging, considering the size of viral particles, detection of possible fossilised viral remains in the vicinity of putative fossilised microorganisms could be a direct proof of the antiquity of viruses and an additional clue to assessing the biogenicity of the observed structures. The oldest known fossil microorganisms, dating back to almost 3.5 billion years $(\mathrm{Ga})$ ago, were preserved as silicified remains (see review in Westall, 2010). The preservation by silica was due to the fact that the early Earth's oceans were silica enriched compared to the undersaturated oceans of the present Earth, where siliceous organ- isms are a sink for available silica. An additional source of silica in the early oceans came from the very active hydrothermal processes cycling silica and other elements from the crust back into the ocean (see review in Westall and Southam, 2006). In situ and experimental silicification of microorganisms in these hydrothermally-influenced environments has been studied in depth over the past two decades (Westall et al., 1995; Toporski et al., 2002; Konhauser et al., 2004; Orange et al., 2009 and references therein). These investigations have provided precious information regarding the processes involved and helped the identification of silicified traces of life in ancient rocks (see review in Westall, 2010). Recent studies have started to explore the ability of viruses to be mineralised and the possibility that they could be preserved in the fossil record. Several studies have studied interactions between different viruses and iron (Daughney et al., 2004; You et al., 2005; Templeton et al., 2006; Kyle et al., 2008b). Daughney et al. (2004) have shown the ability of a marine bacteriophage to interact with dissolved protons, and to act as a site for iron binding, due to the presence of negatively-charged functional groups in its capsid. Kyle et al. (2008b) observed the iron mineralisation of viruses in the acid waters of Rio Tinto (Spain) and discussed the influence of this mineralisation on the biogeochemical processes and on the possibility for viruses to be preserved in the rock record. Poinar and Poinar (2005) reported the possible presence of preserved viruses in 15 to $100 \mathrm{Ma}$ insect preserved in amber. Laidler and Stedman (2010) monitored the experimental fossilisation of bacteriophage $\mathrm{T} 4$ for a few days under simulated hot spring silicifying conditions and showed that silica could precipitate around viral structures and preserve them.

Our study presents the results of the first long-term experimental fossilisation of three viruses and the first experimental fossilisation of viruses hosted by hyperthermophilic Archaea. Among the great variety of viruses in hyperthermophilic Archaea, we chose for this study viruses producing virions (viral particles) with very different structures and morphologies: the rod-shaped virus SIRV2 (Sulfolobus islandicus rod-shaped virus 2) and the spindle-shaped TPV1 (Thermococcus prieurii virus 1) and PAV1 (Pyrococcus abyssi virus 1) viruses. These morphologies appear to be specific for viruses infecting organisms living in extreme environments, either at hot temperatures (rod-shaped, spindleshaped) or with high salt concentrations (spindle-shaped), with the exception of some plant viruses which also produce rod-shaped particles.

Our objectives were (1) to determine whether viruses could be fossilised by silica and whether they could be preserved over relatively long periods of time (several months), and (2) to evaluate whether recognizable features in the viral strains used could still be identified once silica had precipitated around them. 


\section{Materials and methods}

\subsection{Description of the viruses used for this study}

SIRV2 (Sulfolobus islandicus rod-shaped virus 2) belongs to the Rudiviridae family (Prangishvili et al., 1999; Bize et al., 2009) and is a lytic virus (i.e. which causes the death of the host cell) that infects a strain of the Crenarchaeota Sulfolobus islandicus, an acidophilic and hyperthermophilic Archaea that was originally isolated from samples taken from solfataric fields in Iceland (Zillig et al., 1994). SIRV2 particles are stiff rods up to $900 \mathrm{~nm}$ long and $\sim 20 \mathrm{~nm}$ wide (Fig. 1a; Prangishvili et al., 1999) and consist of a superhelix including a protein with double-stranded linear DNA. In contrast to other viruses, such as rod-shaped members of the Lipothrixviridae, SIRV2 virions are not enveloped.

TPV1 (Thermococcus prieurii virus 1) and PAV1 (Pyrococcus abyssi virus 1) were isolated from the Euryarchaeota Thermococcus prieurii strain Bio-pl-0405IT2 and Pyrococcus abyssi strain GE23, respectively (Geslin et al., 2003a; Gorlas et al., 2009). The latter are two neutrophilic and hyperthermophilic Archaea of the Thermococcales order (Erauso et al., 1993; Gorlas et al., 2011). TPV1 and PAV1 are non-lytic, spindle-shaped viruses (TPV1: $140 \times 80 \mathrm{~nm}$; PAV1: $120 \times 80 \mathrm{~nm}$ ), characterised by double-stranded circular DNA, and are found either isolated or in groups (Fig. 1c and d). TPV1 and PAV1 have an envelope composed of viral proteins and lipids from the host. These viruses morphologically resemble members of the Fuselloviridae family but have not yet been classified.

\subsection{Virus isolation}

The viruses used in this study were harvested from fresh cultures of the host strains.

For the production of SIRV2, the Sulfolobus islandicus strain LAL14/1 was grown until the late exponential phase was reached, as described by Zillig et al. (1994). Cells were removed by low-speed centrifugation $(3500 \mathrm{~g}$ in a Sorvall GS3 rotor). The viruses were precipitated from the supernatant by the addition of $1 \mathrm{M} \mathrm{NaCl}$ and $10 \%$ polyethylene glycol 6000 (PEG 6000) and incubated overnight at $4{ }^{\circ} \mathrm{C}$. A pellet of viruses was collected by centrifugation in a Sorvall GSA rotor at $23000 \mathrm{~g}$ for $30 \mathrm{~min}$ and suspended in TA buffer ( $20 \mathrm{mM}$ Tris-acecate, $\mathrm{pH}$ 6). SIRV2 were purified by centrifugation in a $\mathrm{CsCl}$ buoyant density gradient $\left(0.45 \mathrm{~g} \mathrm{ml}^{-1}\right)$ in a Beckman SW41 rotor centrifuge at $250000 \mathrm{~g}$ for $48 \mathrm{~h}$. Fractions containing the viral particles were collected with a syringe then dialyzed against TA buffer for further analysis (Bettstetter et al., 2003). The viruses were stored at $4{ }^{\circ} \mathrm{C}$ in a $20 \mathrm{mM}$ Tris-acetate buffer (pH 6) until used.

Thermococcus prieurii strain Bio-pl-0405IT2 (Gorlas et al., 2011) and Pyrococcus abyssi strain GE23 (Erauso et al., 1993; Marteinsson et al., 1995) were grown in the medium described by Geslin et al. (2003a), at
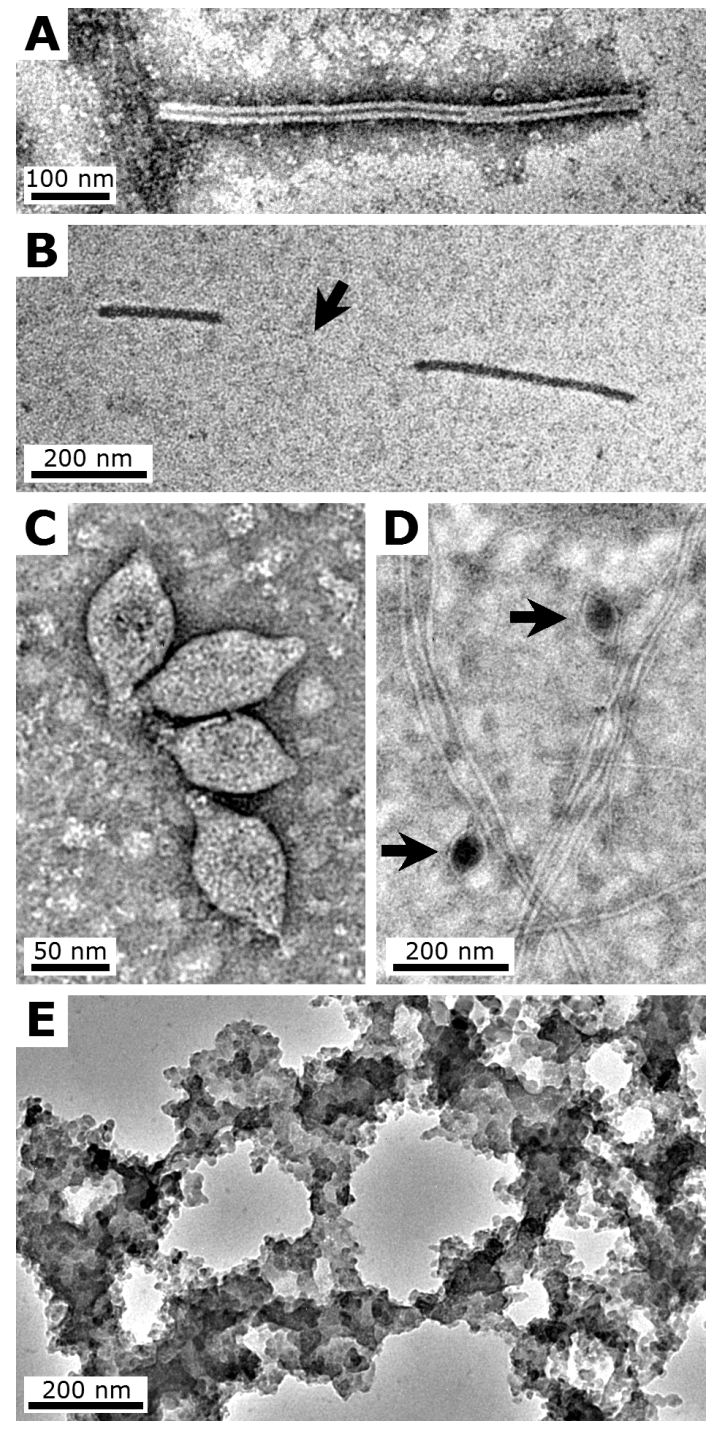

Fig. 1. (A-D): TEM micrographs showing examples of the viruses used for this study. (A) SIRV2 particle; note the central cavity, sometime discontinued. (B) Fragments of SIRV2 particle on an unstained grid; note the absence of visible features, and a viral DNAprotein filament that links the two fragments (arrow). (C) Aggregate of TPV1 particles. (D) PAV1 particles (arrows); note the presence of remnant $P$. abyssi flagellas in the sample. (E) TEM micrograph showing example of the silica precipitate formed spontaneously in the control sample, which contained no viruses, observed after 4 days; unstained grid. All TEM micrographs were made at $200 \mathrm{kV}$ on grids negatively stained with uranyl acetate, unless otherwise stated.

$80^{\circ} \mathrm{C}$ and $85^{\circ} \mathrm{C}$, respectively, up to the late exponential phase. The cells were pelleted by low-speed centrifugation at $6000 \mathrm{~g}$ for $15 \mathrm{~min}$. TPV1 and PAV1 were precipitated from the supernatant in $1 \mathrm{M} \mathrm{NaCl}$ with $10 \% \mathrm{PEG}$ 6000 overnight at $4{ }^{\circ} \mathrm{C}$ with gentle stirring. The precipitate was pelleted by centrifugation at $13000 \mathrm{~g}$ for $1 \mathrm{~h}$ $15 \mathrm{~min}$, then drained and resuspended in a specific buffer 
for each virus (TPV1: TPV1-buffer $-10 \mathrm{mM}$ Tris-HCL, $100 \mathrm{mM} \mathrm{NaCl}, 5 \mathrm{mM} \mathrm{CaCl}_{2}$; PAV1: TE buffer - $10 \mathrm{mM}$ Tris$\mathrm{HCl}$ and $1 \mathrm{mM}$ EDTA, $\mathrm{pH} 8$ ). A second precipitation with PEG $6000(10 \%)$ and $1 \mathrm{M} \mathrm{NaCl}$ was made during $1.5 \mathrm{~h}$ and the precipitate was collected as described above. After centrifugation $(5000 \mathrm{~g}$ for $10 \mathrm{~min}$ ), the supernatant was kept and the pellet was extracted two more times under the same conditions with reduced volumes of TPV1 or TE buffer. The virus-containing supernatants were pooled and stored for one night at $4{ }^{\circ} \mathrm{C}$. After centrifugation $(5000 \mathrm{~g}$ for $15 \mathrm{~min}$ ) to remove residual cell debris, the supernatant was concentrated by ultracentrifugation at $33000 \mathrm{~g}$ for $1 \mathrm{~h} 45 \mathrm{~min}$ (Beckman Optima LE-80K 70.1Ti rotor) and the pellet was resuspended in TPV1 or TE buffer. Viruses were purified from these suspensions by centrifugation in a $\mathrm{CsCl}$ buoyant density gradient (TPV1: $1.32 \mathrm{~g} \mathrm{ml}^{-1}$; PAV1: $1.298 \mathrm{~g} \mathrm{ml}^{-1}$ ) in a Beckman Optima LE-80K 70.1Ti centrifuge rotor (TPV1: $180000 \mathrm{~g}$ for $6 \mathrm{~h}$; PAV1: $220000 \mathrm{~g}$ for $24 \mathrm{~h}$ ). Fractions containing the nucleic acids were detected at $254 \mathrm{~nm}$ and collected using a density gradient fractionator (model 185, ISCO). These fractions were then dialyzed against a large volume of TPV1 or TE buffer and were stored at $4{ }^{\circ} \mathrm{C}$ until used.

\subsection{Silicification procedure}

The fossilisation experiments were made directly in the buffering media of the viruses (SIRV2: Tris-acetate buffer $20 \mathrm{mM}$ Tris-acetate, $\mathrm{pH} 6$; TPV1: TPV1 buffer $-10 \mathrm{mM}$ Tris$\mathrm{HCl}, 100 \mathrm{mM}, 5 \mathrm{mM} \mathrm{CaCl}_{2}$, pH 8; PAV1: TE buffer - $10 \mathrm{mM}$ Tris-HCl, 1 mM EDTA, pH 8). This was done for practical reasons as well as to maintain the viruses in a favourable environment so that their evolution could be followed during fossilisation over several months.

A stock silica solution $(3200 \mathrm{ppm} \mathrm{Si})$ was prepared from a pure sodium silicate solution (Riedel de Haën) containing $\sim 27 \% \mathrm{SiO}_{2}$ and $\sim 10 \% \mathrm{NaOH}\left(\mathrm{Na}_{2} \mathrm{Si}_{3} \mathrm{O}_{7}\right.$, $\mathrm{M}=242 \mathrm{~g} \mathrm{~mol}^{-1}$ ). Its $\mathrm{pH}$ was adjusted to 8 before injection into the virus suspension.

$19 \mu \mathrm{l}$ of a suspension of purified SIRV2 were mixed with $1 \mu \mathrm{l}$ of the stock silica solution in a sealed glass vial to obtain a final concentration of $\sim 160 \mathrm{ppm} \mathrm{Si}$. For TPV1 and PAV1, $180 \mu$ of suspensions of purified viruses were mixed with $20 \mu \mathrm{l}$ of the stock silica solution to obtain a final concentration of $\sim 320 \mathrm{ppm} \mathrm{Si}$. The SIRV2 fossilisation experiment vials were stored at room temperature (due to the small volume, high temperatures led to evaporation). The TPV1 and PAV1 fossilisation experiment vials were placed in an oven at $60^{\circ} \mathrm{C}$. A control sample without viruses, consisting of a $\sim 160 \mathrm{ppm}$ Si silica solution in distilled water, was also prepared and left at room temperature.

The small volumes involved in the experiments meant that we were not able to make precise monitoring of the $\mathrm{pH}$ and silica concentration over time. We assumed that the injection of the silica solution at $\mathrm{pH} 8$ only slightly increased the $\mathrm{pH}$ in the SIRV2 medium, while it did not change the $\mathrm{pH}$ of the TPV1 and PAV1 media.

\subsection{Electron microscopy}

The vials were sampled at different times (between 2 and 60 days for the SIRV2 experiment; between 1 and 180 days for the TPV1 and PAV1 experiments; 4 days for the control sample) by collecting $\sim 1 \mu \mathrm{l}$ of the sample and immediately preparing it for negatively-stained transmission electron microscopy (Geslin et al., 2003a).

For negative staining, a droplet of sample (either unsilicified or silicificed) was placed on a carbon-coated copper TEM grid. The sample was allowed to absorb to the carbon layer for $2 \mathrm{~min}$ before removing the excess liquid with a piece of filter paper. Some samples were stained to increased contrast by placing a droplet of saturated uranyl acetate ethanolic solution for $40 \mathrm{~s}$ and then removing the excess liquid. Some grids were also observed unstained to better distinguish silica deposition on the viral structures. The prepared samples were then air dried. They were observed and analysed with a Philips CM20 Transmission Electron Microscope (Centre de Microscopie Electronique, University of Orléans), equipped with an EDX detector (Oxford Instruments).

\section{Results}

\subsection{Experimental fossilisation of SIRV2}

SIRV2 particles appear as stiff rods of several hundreds of nanometers in length and $\sim 20 \mathrm{~nm}$ in width and contain a central cavity (Fig. 1a), not visible on unstained grids (Fig. 1b). This virion is naturally fragile and readily breaks up into fragments that may be linked to each other by filaments, identified as the result of the degradation of the viral helix and made of DNA with remnants of the viral protein (Fig. 1b, arrow) (Prangishvili et al., 1999; Vertergaard et al., 2008). Apart from fragmentation, the preservation of SIRV2 fragments during fossilisation was generally good. In the first days of the fossilisation experiment, a granular and alveolartextured silica precipitate formed spontaneously in both the control experiment without viruses (Fig. 1e) and in the experiment with the viruses (Fig. 2a, b), indicating that neither virus particles nor the buffering medium had any influence on precipitation or on the structure of the silica. Initially, after one week of fossilisation only a few SIRV2 particles were observed in direct contact with, and sometimes trapped within, the silica precipitate (Fig. 2a) but most were not (Fig. 2b). Where embedded in the silica deposit, the viral helix appeared to have been compacted or decayed and the virion was only visible as a faint, dark outline (Fig. 2a, arrows) that probably represents degraded viral DNA and protein. Silica nucleation on the virion was observed after 1 week (Fig. 2c, arrow) and, after 30 days, nanometric 

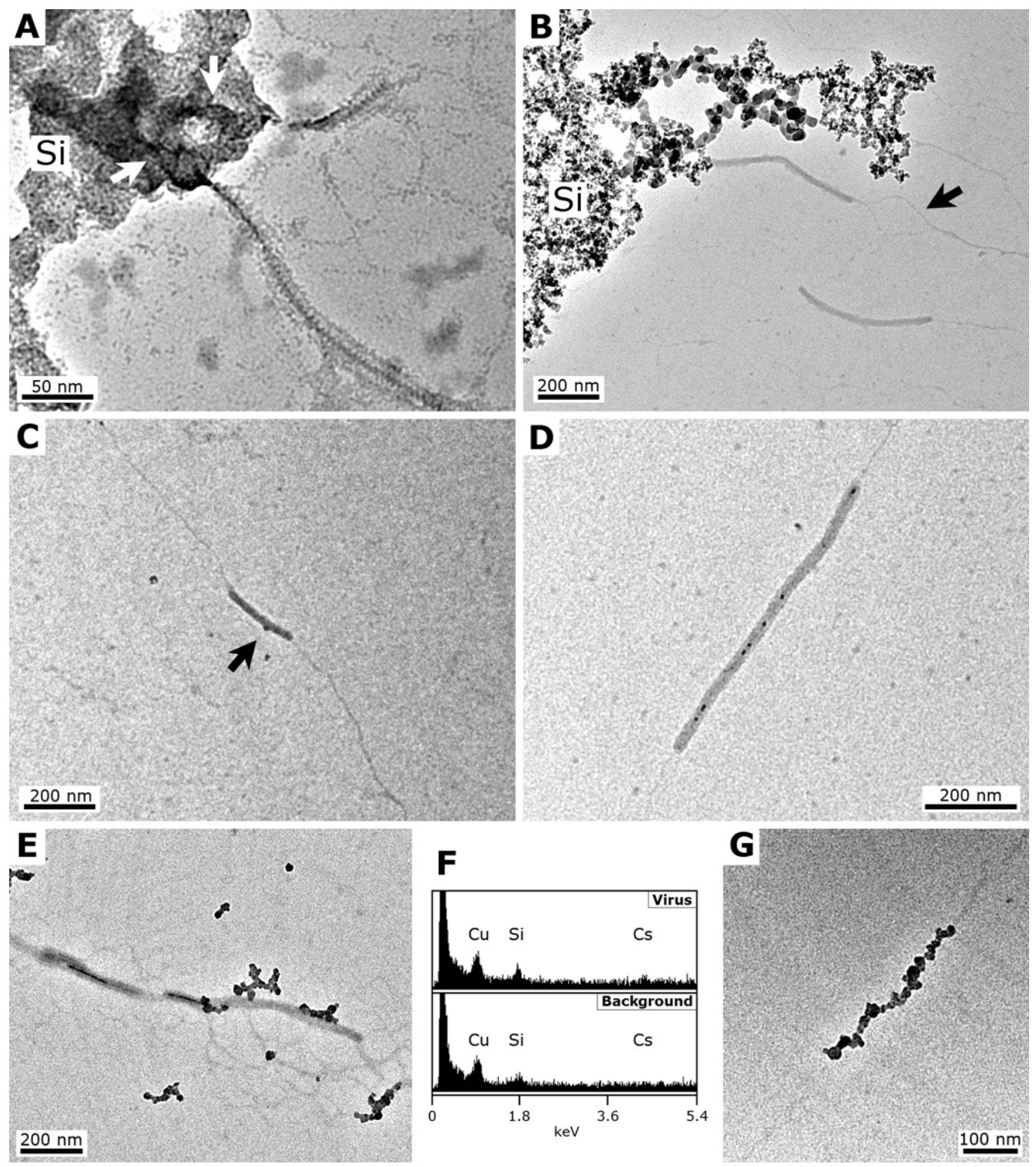

Fig. 2. TEM micrographs showing progressive steps of the experimental fossilisation of SIRV2 at a $\sim 160 \mathrm{ppm} \mathrm{Si} \mathrm{silica} \mathrm{concentration.}$ (A) $48 \mathrm{~h}$, SIRV2 particle partially trapped inside the silica precipitate (Si); the arrows underline the shape of the virion inside the precipitate. (B) 7 days, fragments of SIRV2 particles in the vicinity of a silica precipitate ( $\mathrm{Si}$ ); the two separated filaments of viral DNA-protein are visible (arrow). (C) 7 days, unstained grid, fragment of SIRV2 particle; a dark $\sim 10 \mathrm{~nm}$ particle is seen attached on the virion (arrow). (D) 30 days, SIRV2 particle; note the numerous dark silica particles in the central cavity. (E) 60 days, unstained grid, fragments of SIRV2 particle; note the dark silica particles attached on the outer surface of the virion, and filling the central cavity. (F) 60 days, EDX spectra made on the SIRV2 particles of (E), showing a Si signal slightly higher than on the background; the Cs signal comes from the cesium chloride used for virus purification and the $\mathrm{Cu}$ signal comes from the copper grid. (G) 60 days, unstrained grid, viral DNA-protein filament covered by silica particles. All TEM micrographs were made at $200 \mathrm{kV}$ on grids negatively stained with uranyl acetate, unless otherwise stated.

dark particles had formed in the central cavity of some of the virions (Fig. 2d). This phenomenon was more evident after 60 days of fossilisation with virions showing, on unstained grids, a strongly contrasted central cavity (Fig. 2e), suggesting that the individual particles observed previously had continued their growth and eventually merged. More pronounced silica nucleation and binding on the outside of the viral particles was also observed. EDX analyses made on these particles showed a silicium signal slightly stronger than the signal from background noise (Fig. 2f). Fine chains of silica particles (Fig. $2 \mathrm{~g}$ ) may represent silica directly precipitated on isolated viral DNA-protein filaments, or the remnants of virion fragments completely covered by silica. 


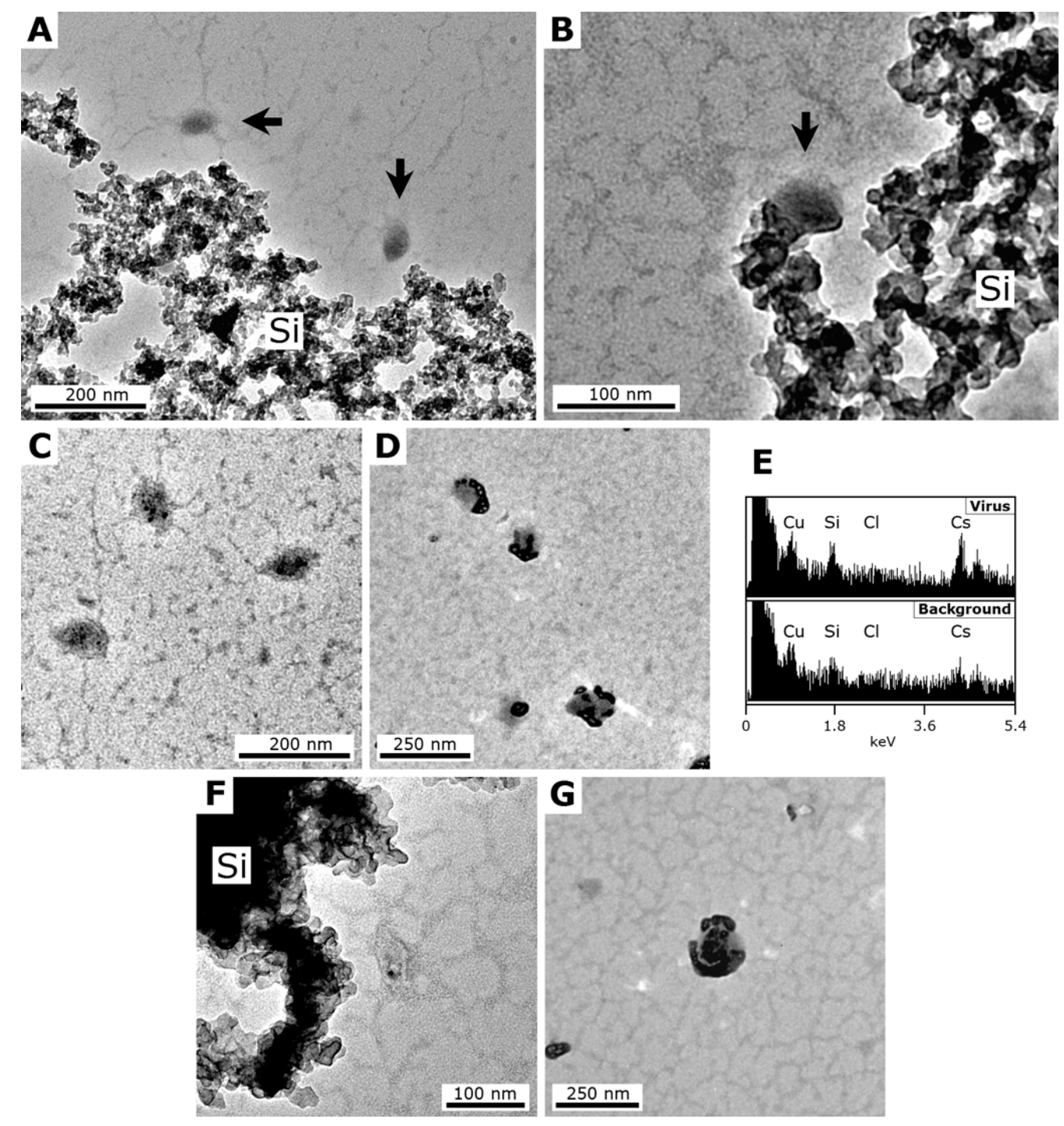

Fig. 3. TEM micrographs showing progressive steps of the experimental fossilisation of TPV1 at a $\sim 320 \mathrm{ppm} \mathrm{Si} \mathrm{silica} \mathrm{concentration.}$ (A) 1 week, two TPV1 particles (arrows) near a silica precipitate (Si). (B) 1 month, TPV1 particle (arrow) attached to the silica precipitate (Si). (C) 75 days, TPV1 particles with dark nanometric particles within. (D) 75 days, unstained grid, TPV1 particles on which a dark precipitate has formed. (E) 75 days, EDX spectra obtained on the virions of (D) and on the background, showing Si and Cs signals on the precipitate; the $\mathrm{Cl}$ signal comes from buffering medium and the $\mathrm{Cu}$ signal comes from the copper grid. (F) 180 days, deformed TPV1 particle near a silica precipitate (Si); note the dark particle within. (G) 180 days, unstained grid, TPV1 particle covered and filled with a dark precipitate. All TEM micrographs were made at $200 \mathrm{kV}$ on grids negatively stained with uranyl acetate, unless otherwise stated.

\subsection{Experimental fossilisation of TPV1 and PAV1}

Although a granular, alveolar silica precipitate formed spontaneously within one day of the experiment, similar to that observed in the SIRV2 and control experiments (Fig. 3a), it was only after 30 days that the TPV1 particles were observed in direct contact with the precipitate (Fig. 3b). No virions trapped in the silica precipitate were observed. The first signs of possible silica precipitation on the viral structures occurred only after 75 days when nanometer sized, dark particles were observed within (Fig. 3c) and on the envelope of some of the virus particles (Fig. 3d). In the latter case, EDX analyses (Fig. 3e) indicate that this precipitate consists of both silica and cesium, the latter being derived from the purification buffer. Such a precipitate had not been observed in earlier steps of the experiment nor on unfossilised viruses particles. After 180 days, the virions were significantly degraded (Fig. 3f). Some of the viral particles contained only a few nanoparticles of silica within their structure (Fig. 3f) while some others were heavily coated and impregnated with the apparently-progressing $\mathrm{SiO}_{2}$-Cs precipitate (Fig. 3g). 

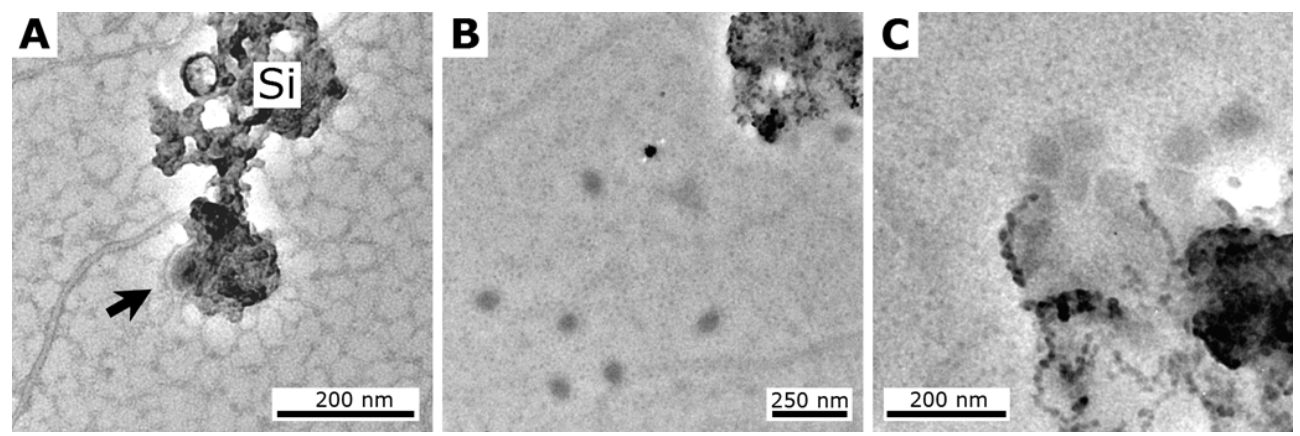

Fig. 4. TEM micrographs showing progressive steps of the experimental fossilisation of PAV1 at a $\sim 320 \mathrm{ppm} \mathrm{Si} \mathrm{silica} \mathrm{concentration.}$ (A) 1 day, PAV1 particle (arrow) attached to the silica precipitate (Si). (B) 60 days, unstained grid, numerous PAV1 particles near the silica precipitate. (C) 60 days, unstained grid, aggregate of PAV1 particles trapped in a finely grained silica precipitate. All TEM micrographs were made at $200 \mathrm{kV}$ on grids negatively stained with uranyl acetate, unless otherwise stated.

Monitoring of the PAV1 fossilisation experiment was complicated by the presence of numerous fragments of $P$. abyssi flagella as well as numerous artefacts in the preparation of purified PAV1 (Fig. 1d). PAV1 particles could be observed in direct contact with the silica precipitate after only 1 day (Fig. 4a). This precipitate was different from that formed in the SIRV2 and TPV1 experiments and consisted of very fine particles (compare Figs. 4c and 3b). The reason for this is unknown, although it possibly could be a consequence of the different composition of the PAV1 buffering medium (which includes EDTA, a chelating and binding agent). No precipitates formed inside or on free PAV1 particles after 60 days (Fig. 4b), although several virus particles were seen at the edge of the silica precipitate (Fig. 4c), suggesting that an important number of PAV1 particles had been trapped in it.

\section{Discussion}

The viruses used in this experiment belong to different virus families having completely different morphologies and structures. This may partly explain why the results of the fossilisation experiments were different. In the case of SIRV2, a non-enveloped rod-shaped virus, silica binding on the viral particles was significant and progressive whereas only limited silica binding occurred on TPV1 and PAV1, enveloped spindle-shaped viruses.

\subsection{Fossilisation of the viruses}

We assumed (but could not verify, due to the small volumes of the samples) that the silica behaviour during the experiments was similar to that described in previous experimental fossilisation studies (review in Konhauser et al., 2004). Upon injection into the vials, silica was in monomeric $\left(\mathrm{Si}(\mathrm{OH})_{4}\right)$ or slightly polymeric form and quickly spontaneously polymerised as a colloidal amorphous silica precipitate. Dissolved silica must have remained in the medium after this initial polymerisation at a concentration close to the saturation concentration (62 ppm Si in distilled water; Gunnarsson and Arnórsson, 2000; Lalonde et al., 2005). In support of this, the silica precipitate formed in the SIRV2, TPV1 and control experiments was similar to that observed in previous fossilisation experiments (Orange et al., 2009).

The fact that the silica precipitates in the SIRV2 experiment were invariably linked to viral DNA-protein filaments (Fig. 2b) suggests that the spontaneously-formed silica deposit probably rapidly entrapped numerous SIRV2 particles, as was observed by Laidler and Stedman (2010). Some particles were barely observable as dark outlines within the mineral precipitate (Fig. 2a). The viral particles that remained free in the medium showed progressive silica binding with time on their outer surface and in their central cavity. Initial silica nucleation within the cavity of the SIRV2 particles did not appear to damage the body (Fig. 2d, e) although, at later steps of the fossilisation process, strings of silica particles observed on DNA-protein filaments (Fig. 2g) suggest that viral particles may be heavily damaged by the growth of silica. The rarity of silicified DNA-protein filaments may be due to the fact that DNA degrades rapidly when exposed to the environment (Schelble et al., 2008), while the remains of DNA trapped in silica (Fig. 2a, g) may be preserved. Silica binding to the outer surface of the virions appears to be the result of two mechanisms: (i) the direct nucleation of silica (Fig. 2c) followed by continuing polymerisation, resulting in the formation of hemispherical silica particles that progressively grow and merge (Fig. 2c, e); (ii) the binding of already formed silica particles on the virions, or on previously bound silica particles (e.g. the middle silica particle among the three attached to SIRV2 particle in Fig. 2e, which has a similar aspect to the free particles present around the virion). These mechanisms have previously been described in studies of the fossilisation of microorganisms (Birnbaum et al., 1989; Schultze-Lam et al., 1995; Westall et al., 1995; Toporski et al., 2002; Orange et al., 2009). Silica probably binds via covalent or hydrogen bonds between the silica 
particles and the hydroxyl and/or carboxyl functional groups contained in the protein of the helix (see review of the fossilisation processes in Konhauser et al., 2004).

Fossilisation of the viruses TPV1 and PAV1 differed from that of SIRV2. The former have an envelope that contains lipids that derive from the hosts (the Archaea P. abyssi and T. prieurii, respectively) (Geslin et al., 2003a; Gorlas et al., 2011). Previous results from the experimental fossilisation of Archaea showed that the simple cell wall of these microorganisms (S-Layer + plasma membrane) has only a limited ability to bind silica (Orange et al., 2009). It was therefore to be expected that, having a similar composition, the envelopes of TPV1 and PAV1 would not bind significant amounts of silica. This was indeed observed for TPV1, although some virions occasionally occurred in direct contact with silica (Fig. 3b), and, after 75 days of exposure to the silica solution, nanometer-sized particles were ubiquitously observed inside TPV1 (Fig. 3c, f). Only at this advanced stage in the fossilisation procedure (75 days), were nanoparticles of a $\mathrm{SiO}_{2}-\mathrm{Cs}$ precipitate first observed on the virion envelopes (Fig. 3d). The source of the $\mathrm{Cs}$ was the cesium chloride used for harvesting purified TPV1. Chelated metal ions may act as bridges in the fixation of mineral ions to organic materials. This has been demonstrated with Fe(III) chelated to Bacteria and Archaea (Beveridge and Murray, 1976; Beveridge and Koval, 1981; Orange et al., 2011). However, as a monovalent cation, $\mathrm{Cs}^{+}$cannot act as a direct intermediate between silica and the virion envelope or internal materials. Silica binding to the TPV1 particles most likely occurred in the same way as with the SIRV2 particles, namely through covalent or hydrogen bonding of the silica. Similar results for TPV1 and PAV1 were expected, since these two viruses have similar structures. Instead, no silica precipitation was observed on free PAV1 particles (Fig. 4b) while numerous virions were trapped in the silica precipitate (Fig. 4c). The unknown factors that led to the formation of a different silica precipitate may also be responsible of these differences in the silicification process.

\subsection{Implication for the preservation and identification of viral remains in rocks}

The three viruses used in this artificial fossilisation study were well preserved, apart from a slight deformation possibly due to the length of the experiment rather than to the exposure to silica. The fossilisation was made directly on virions stored in buffered solutions, which is obviously not a natural condition. The rationale for making the experiments on the microorganisms in a buffered solution is the previously noted importance for the cell to remain alive, or at least not to lyse, during the time necessary for silica to form a deposit around the cells thick enough to allow for fossilisation and further preservation (Orange et al., 2009). This period of time varies depends on the strain or the type of microorganism. Viral particles obviously do not lyse but their physical integrity can quickly be affected due to their small size and constitution. Our results show that, if viral particles can be conserved over several months, they can theoretically become fossilised. In addition, our results suggest that viral particles may have been trapped in the silica precipitate, with viral remains being possibly preserved, although the quality of the preservation could not be precisely ascertained in this case.

The fact that viruses can be fossilised suggests that naturally fossilised viruses may occur in rocks in the same way as fossilised microbial cells. The question is, how could we identify them? Morphology is a criterion for their identification but their simple nanometric-sized structures may be confused with minerals or other artifacts of the same size (of the order of $\sim 100 \mathrm{~nm}$ ). On the other hand, it may be possible to identify filamentous or rod-shaped structures, such as the about $500 \times 20 \mathrm{~nm}$-sized SIRV2 particles, in ancient rocks. These viruses are about the same size and shape as the socalled "nanobacteria" identified in 3.9 Ga old carbonate concretions in the Martian meteorite ALH 84001 (McKay et al., 1996 - note that it is now accepted that the latter are simply mineral precipitations; Gibson Jr. et al., 2001). Although silica precipitated in the central cavity of SIRV2 (Fig. 2e) as a structure of less than $10 \mathrm{~nm}$ in width and several hundreds of nanometers long, it would be difficult to distinguish such a feature from polymeric fibrils or filaments of other biological origin that had been silicified. Viral organic compounds, such as lipids and proteins, could also be preserved in very small amounts but they would rapidly be degraded, hence rendering their detection and identification as viral biomarkers difficult. Thus, even though it is theoretically feasible, detection of virus remains in rocks will be highly challenging.

\section{Conclusions}

This study is one of the first attempts to fossilise viruses and the first monitoring of the fossilisation of viruses of extremophilic Archaea over a period of several months. Our results show that the viruses of extremophilic microorganisms can be fossilised by silica and that the structures have a chance of being preserved if the process can take place over a period of several months. The virus structure and the molecular composition of their outer surface (lipid envelope, protein) clearly play a role in the rate and manner of fossilisation. Although faithful preservation of the viral structures over geological time is probably unlikely, some traces may nevertheless remain in rocks. Our study thus contributes important information to this new field of research. Due to the great diversity of viruses in terms of morphology and structure, additional studies are needed to complete these results with the fossilisation of other kinds of virus in order to better understand the mechanisms involved. 
Acknowledgements. This research was funded by the CNRS - PID Origines des Planètes et de la Vie (2007-2009). Aurore Gorlas was funded through a Ph.D. grant from the Ministère de l'Enseignement Supérieur et de la Recherche. Dominique Jalabert is thanked for his aid with the transmission electron microscope.

Edited by: J. Toporski

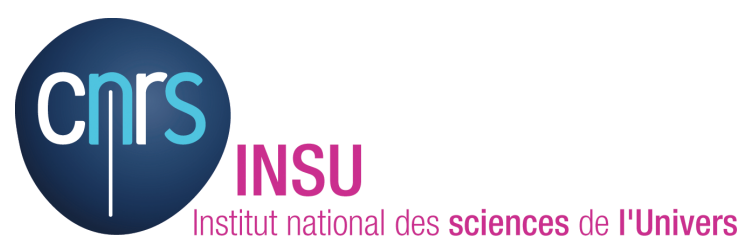

The publication of this article is financed by CNRS-INSU.

\section{References}

Bamford, D. H.: Do viruses form lineages across different domains of life?, Res. Microbiol. 154, 231-236, doi:10.1016/S09232508(03)00065-2, 2003.

Bamford, D. H., Grimes, J. M., and Stuart, D. I.: What does structure tell us about virus evolution?, Curr. Opin. Struc. Biol., 15, 655-663, doi:10.1016/j.sbi.2005.10.012, 2005.

Bettstetter, M., Peng, X., Garrett, R. A., and Prangishvili, D.: AFV1, a novel virus infecting hyperthermophilic archaea of the genus Acidianus, Virology, 315, 68-79, 2003.

Beveridge, T. J. and Koval, S. F.: Binding metals to cell envelopes of Escherichia coli, Appl. Environ. Microb., 42, 325-335, 1981.

Beveridge, T. J. and Murray, R. G. E.: Uptake and retention of metals by cell walls of Bacillus subtilis, J. Bacteriol., 127, 15021518, 1976.

Bird, D. F., Juniper, S. K., Ricciardi-Rigault, M., Martineu, P., Prairie, Y. T., and Calvert, S. E.: Subsurface viruses and bacteria in Holocene/Late Pleistocene sediments of Saanich Inlet, BC: ODP Holes 1033B and 1034B, Leg 169S, Mar. Geol., 174, 227-239, doi:10.1016/S0025-3227(00)00152-3, 2001.

Birnbaum, S. J., Wireman, J. W., and Borowski, R.: Silica precipitation by the anaerobic sulphate reducing bacterium Desulfovibrio desulfuricans: effects upon cellmorphology and implications for preservation, in: Origin, Evolution, and Modern Aspects of Biomineralization in Plants and Animals, Crick, R.E., Plenum Press, New York, USA, 507-516, 1989.

Bize, A., Karlsson, E. A., Ekefjärd, K., Quax, T. E. F., Pina, M., Prevost, M. C., Forterre, P., Tenaillon, O., Bernander, R., and Prangishvili, D.: A unique virus release in the Archaea, P. Natl. Acad. Sci. USA, 106, 11306-11311, doi:10.1073/pnas.0901238106, 2009.

Borriss, M., Helmke, E., Hanschke, R., and Schweder, T.: Isolation and characterization of marine psychrophilic phagehost systems from Arctic sea ice, Extremophiles, 7, 377-384, doi:10.1007/s00792-003-0334-7, 2003.

Daughney, C. J., Châtellier, X., Chan, A., Kenward, P., Fortin, D., Suttle, C. A., and Fowle, D. A.: Adsorption and precipitation of iron from seawater on a marine bacteriophage (PWH3A-P1), Mar. Chem., 91, 101-115, doi:10.1016/j.marchem.2004.06.003, 2004.
Dyall-Smith, M., Tang., S. L., and Bath, C.: Haloarchaeal viruses: how diverse are they?, Res. Microbiol., 154, 309-313, doi:10.1016/S0923-2508(03)00076-7, 2003.

Erauso, G., Reysenbach, A. L., Godfroy, A., Meunier, J. R., Crump, B., Partensky, F., Baross, J. A., Marteinsson, V., Barbier, G., Pace, N. R., and Prieur, D.: Pyrococcus abyssi sp. nov., a new hyperthermophilic archaeon isolated from a deep-sea hydrothermal vent, Arch. Microbiol., 160, 338-349, 1993.

Forterre, P.: A hot story from comparative genomics: reverse gyrase is the only hyperthermophile-specific protein, Trends Genet., 18, 236-238, doi:10.1016/S0168-9525(02)02650-1, 2002.

Forterre, P.: Three RNA cells for ribosomal lineages and three DNA viruses to replicate their genomes : A hypothesis for the origin of cellular domain, P. Natl. Acad. Sci. USA, 103, 3669-3674, doi:10.1073/pnas.0510333103, 2006.

Forterre, P.: Manipulation of cellular syntheses and the nature of viruses: The virocell concept, C.R. Chim., 14, 392-399, doi:10.1016/j.crci.2010.06.007, 2011.

Forterre, P. and Prangishvili, D.: The great billion-year war between ribosome- and capsid-encoding organisms (cells and viruses) as the major source of evolutionary novelties, Ann. NY. Acad. Sci., 1178, 65-77, doi:10.1111/j.1749-6632.2009.04993.x, 2009a.

Forterre, P. and Prangishvili, D.: The origin of viruses, Res. Microbiol., 160, 466-472, doi:10.1016/j.resmic.2009.07.008, 2009b.

Geslin, C., Le Romancer, M., Erauso, G., Gaillard, M., Perrot, G., and Prieur, D.: PAV1, the first virus-like particle isolated from a hyperthermophilic Euryarchaeote, Pyrococcus abyssi, J. Bacteriol., 185, 3888-3894, doi:10.1128/JB.185.13.3888-3894.2003, 2003a.

Geslin, C., Le Romancer, M., Gaillard, M., Erauso, G., and Prieur, P.: Observation of virus-like particles in high temperature enrichment cultures from deep-sea hydrothermal vents, Res Microbiol., 154, 303-307, doi:10.1016/S0923-2508(03)00075-5, $2003 \mathrm{~b}$.

Geslin, C., Le Romancer, M., Gaillard, M., and Prieur, D.: Diversité virale associée aux écosystèmes hydrothermaux océaniques profonds et aux sources chaudes terrestres, Virologie, 9, 357-366, 2005.

Gibson Jr., E. K., McKay, D. S., Thomas-Keprta, K. L., Wentworth, S. J., Westall, F., Steele, A., Romanek, C. S., Bell, M. S., and Toporski, J.: Life on Mars: evaluation of the evidence within Martian meteorites ALH 84001, Nakhla and Shergotty, Precambrian Res., 106, 15-34, doi:10.1016/S0301-9268(00)00122-4, 2001.

Gorlas, A., Geslin, C., and Prieur, D.: TV1, the first virus-like particle of Thermococcus, a hyperthermophilic Archaea genus, Origins Life Evol. B., 39, p. 62, 2009.

Gorlas, A., Alain, K., Bienvenu, N., Isaac, S., and Geslin, C.: Thermococcus prieurii sp. nov., a novel hyperthermophilic archaeon isolated from a deep-sea hydrothermal vent at the East Pacific Rise, Int. J. Syst. Evol. Micr., submitted, 2011.

Gowing, M. M.: Large viruses and infected microeukaryotes in Ross Sea summer pack ice habitats, Mar. Biol., 142, 1029-1040, doi:10.1007/s00227-003-1015-x, 2003.

Gunnarsson, I. and Arnórsson, S.: Amorphous silica solubility and the thermodynamic properties of $\mathrm{H}_{4} \mathrm{SiO}_{4}^{\circ}$ in the range of $0^{\circ}$ to $350^{\circ} \mathrm{C}$ at $\mathrm{P}_{\mathrm{sat}}$, Geochim. Cosmochim. Ac., 64, 2295-2307, doi:10.1016/S0016-7037(99)00426-3, 2000.

Jiang, S., Steward, G., Jellison, R., Chu, W., and Choi, S.: Abundance, distribution and diversity of viruses in alkaline 
hypersaline Mono Lake, California, Microb. Ecol., 47, 9-17, doi:10.1007/s00248-003-1023-x, 2004.

Kepner, R. L., Wharton Jr., R. A., and Suttle, C. A.: Viruses in Antarctic lakes, Limnol. Oceanogr., 43, 1754-1761, 1998.

Konhauser, K. O., Jones, B., Reysenbach, A. L., and Renaut, R. W.: Hot spring sinters: Keys to understanding Earth's earliest life forms, Can. J. Earth Sci., 40, 1713-1724, 2003.

Konhauser, K. O., Jones, B., Phoenix, V. R., Ferris, G., and Renaut, R. W.: The microbial role in hot spring silicification, Ambio, 33, 552-558, 2004.

Koonin, E. V. and Dolja, V. V.: Evolution of complexity in the viral world: the dawn of a new vision. Virus Res., 117, 1-4, doi:10.1016/j.virusres.2006.01.018, 2006.

Koonin, E. V., Senkevich, T. G., and Dolja, V. V.: The ancient virus world and evolution of cells, Biol. Direct, 1, 29, doi:10.1186/1745-6150-1-29, 2006.

Krupovic, M. and Bamford, D. H.: Virus evolution: how far does the double beta-barrel viral lineage extend?, Nat. Rev. Microbiol., 6, 941-9488, doi:10.1038/nrmicro2033, 2008.

Kyle, J. E., Eydal, H. S. C., Ferris, F. G., and Pedersen, K.: Viruses in granitic groundwater from 69 to $450 \mathrm{~m}$ depth of the Äspö hard rock laboratory, Sweden, ISME J., 2, 571-574, doi:10.1038/ismej.2008.18, 2008a.

Kyle, J. E., Pedersen, K., and Ferris, F. G.: Virus mineralization at low $\mathrm{pH}$ in the Rio Tinto, Spain, Geomicrobiol. J., 25, 338-345, doi:10.1080/01490450802402703, 2008 b.

Laidler, J. R. and Stedman, K. M.: Virus silicification under simulated hot spring conditions, Astrobiology, 10, 569-576, doi:10.1089/ast.2010.0463, 2010.

Lalonde, S. V., Konhauser, K. O., Reysenbach, A. L., and Ferris, F. G.: The experimental silicification of Aquificales and their role in hot spring formation, Geobiology, 3, 41-52, doi:10.1111/j.14724669.2005.00042.x, 2005.

La Scola, B., Audic, S., Robert, C., Jungang, L., de Lamballerie, X., Drancourt, M., Birtles, R., Claverie, J. M., and Raoult, D.: A giant virus in Amoebae, Science, 299, p. 2033, doi:10.1126/science.1081867, 2003.

Le Romancer, M., Gaillard, M., Geslin, C., and Prieur, D.: Viruses in extremes environments, Reviews in Environmental Science and Biotechnology, 6, 17-31, doi:10.1007/s11157-006-0011-2, 2007.

Maranger, R., Bird, D. F., and Juniper, S. K.: Viral and bacterial dynamics in Arctic sea ice during the spring algal bloom near Resolute, N.W.T., Canada, Mar. Ecol.-Prog. Ser., 111, 121-127, 1994.

Marteinsson, V. T., Watrin, L., Prieur, D., Caprais, J. C., Raguénès, G., and Erauso G.: Phenotypic characterization, DNA similarities, and protein profiles of twenty sulfur-metabolizing hyperthermophilic anaerobic Archaea isolated from hydrothermal vents in the southwestern Pacific Ocean, Int. J. Syst. Bacteriol., 45, 623-632, doi:10.1099/00207713-45-4-623, 1995.

Martin, A., Yeats, S., Janekovic, D., Reiter, W. D., Aicher, W., and Zillig, W.: SAV1, a temperate u.v.-inducible DNA virus-like particle from the archarbacterium Sulfolobus acidocaldarius isolate B12, EMBO J., 3, 2165-2168, 1984.

McKay, D. S., Gibson Jr., E. K., Thomas-Keprta, K. L., Vali, H., Romanek, C. S., Clemett, S. J., Chillier, X. D. F., Maechling, C. R., and Zare, R. N.: Search for Past Life on Mars: Possible Relic Biogenic Activity in Martian Meteorite ALH84001, Sci- ence, 273, 924-930, doi:10.1126/science.273.5277.924, 1996.

Moreira, D. and López-García, P.: Ten reasons to exclude viruses from the tree of life, Nat. Rev. Microbiol., 7, 306-311, doi:10.1038/nrmicro2108, 2009.

Nisbet, E. G. and Sleep, N. H.: The habitat and nature of early life, Nature, 409, 1083-1091, doi:10.1038/35059210, 2001.

Orange, F., Westall, F., Disnar, J. R., Prieur, D., Bienvenu, N., Le Romancer, M., and Défarge, C.: Experimental silicification of the extremophilic Archaea Pyrococcus abyssi and Methanocaldococcus jannaschii. Applications in the search for evidence of life in early Earth and extraterrestrial rocks, Geobiology, 7, 403418, doi:10.1111/j.1472-4669.2009.00212.x, 2009.

Orange, F., Disnar, J. R., Westall, F., Prieur, D., and Baillif, P.: Metal cation binding by the hyperthermophilic microorganism, Archaea Methanocaldococcus jannaschii, and its effects on silicification, Palaeontology, accepted, 2011.

Oren, A., Bratbak, G., and Heldal, M.: Occurrence of virus like particles in the Dead Sea, Extremophiles, 1, 143-149, doi:10.1007/s007920050027, 1997.

Ortmann, A. C. and Suttle, C. A.: High abundances of viruses in deep-sea hydrothermal vent system indicate viral mediated microbial mortality, Deep-Sea Res. Pt. I, 52, 1515-1527, doi:10.1016/j.dsr.2005.04.002, 2005.

Ortmann, A. C., Wiedenheft, B., Douglas, T., and Young, M.: Hot crenarchaeal viruses reveal deep evolutionary connections, Nat. Rev. Microbiol., 4, 520-528, doi:10.1038/nrmicro1444, 2006.

Pagaling, E., Haigh, R. D., Grant, W. D., Cowan, D. A., Jones, B. E., Ma, Y., Ventosa, A., and Heaphy, S.: Sequence analysis of an Archaeal virus isolated from a hypersaline lake in Inner Mongolia, China, BMC Genomics, 8, 410, doi:10.1186/14712164-8-410, 2007.

Poinar, G. P. and Poinar, R.: Fossil evidence of insect pathogens, J. Invertebr. Pathol., 89, 243-250, doi:10.1016/j.jip.2005.05.007, 2005.

Prangishvili, D., Arnold, H. P., Götz, D., Ziese, U., Holz, I., Kristjansson, J. K., and Zillig, W.: A novel virus family, the Rudiviri$d a e$ : Structure, virus-host like interactions and genome variability of the Sulfolobus viruses SIRV1 and SIRV2, Genetics, 152, 1387-1396, 1999.

Prangishvili, D., Forterre, P., and Garrett, R. A.: Viruses of the Archaea: a unifying view, Nat. Rev. Microbiol., 4, 837-848, doi:10.1038/nrmicro1527, 2006a.

Prangishvili, D., Garrett, R. A., and Koonin, E. V.: Evolutionary genomics of archaeal viruses: unique viral genomes in the third domain of life, Virus Res., 117, 52-67, doi:10.1016/j.virusres.2006.01.007, 2006b.

Prigent, M., Leroy, M., Confalonieri, F., Dutertre, M., and DuBow M. S.: A diversity of bacteriophage forms and genomes can be isolated from the surface sands of the Sahara Desert, Extremophiles, 9, 289-296, doi:10.1007/s00792-005-0444-5, 2005.

Rachel, R., Bettstetter, M., Hedlund, B. P., Häring, M., Kessler, A., Stetter, K. O., and Prangishvili, D.: Remarkable morphological diversity of viruses and virus-like particles in hot terrestrial environments, Arch. Virol., 147, 2419-2429, doi:10.1007/s00705002-0895-2, 2002.

Raoult, D., Audic, S., Robert, C., Abergel, C., Renesto, P., Ogata H., La Scola, B., Suzan, M., and Claverie, J. M.: The 1.2megabase genome sequence of Mimivirus, Science, 306, 1344 1350, doi:10.1126/science.1101485, 2004. 
Rice, G., Stedman, K., Snyder, J., Wiedenheft, B., Willits, D., Brumfield, S., and McDermott, T.: Viruses from extreme thermal environments, P. Natl. Acad. Sci. USA, 98, 13341-13345, doi:10.1073/pnas.231170198, 2001.

Schelble, R. T., Hall, J. A., Nealson, K. H., and Steele, A.: DNA perseverance of microorganisms exposed to silica: an experimental study, Geobiology, 6, 503-511, doi:10.1111/j.14724669.2008.00177.x, 2008.

Schultze-Lam, S., Ferris, F. G., Kohnauser, K. O., and Wiese, R. G.: In situ silicification of an Icelandic microbial mat: implications for microfossil formation, Can. J. Earth Sci., 32, 20212026, 1995.

Sime-Ngando, T., Lucas, S., Robin, A., Pause Tucker, K., Colombet, J., Bettarel, Y., Desmond, E., Gribaldo, S., Forterre, P., Breitbart, M., and Prangishvili, D.: Diversity of virus-host systems in hypersaline Lake Retba, Senegal, Environ. Microbiol., doi:10.1111/j.1462-2920.2010.02323.x, in press, 2010.

Templeton, M. R., Andrews, R. C., and Hofmann, R.: Impact of iron particles in groundwater on the UV inactivation of bacteriophages MS2 and T4, J. Appl. Microbiol., 101, 732-741, doi:10.1111/j.1365-2672.2006.02980.x, 2006.

Toporski, J. K. W., Steele, A., Westall, F., Thomas-Keprta, K. L., and McKay, D. S.: The simulated silicification of bacteria - new clues to the modes and timing of bacterial preservation and implications for the search for extraterrestrial microfossils, Astrobiology, 2, 1-26, 2002.
Vestergaard, G., Shah, S. A., Bize, A., Reitberger, W., Reuteur, M., Phan, H., Brigel, A., Rachel, R., Garrett, R. A., and Prangishvili, D.: Stygiolobus Rod-Shaped Virus and the interplay of Crenarchaeal Rudiviruses with the CRISPR Antiviral System, J. Bacteriol., 190, 6837-6845, doi:10.1128/JB.00795-08, 2008.

Westall, F.: Early life: nature, distribution and evolution, in: Origins and evolution of life, an astrobiological perspective, edited by: Gargaud, M., López-García, P., and Martin, H., Cambridge University Press, Cambridge, United-Kingdom, 391-413, 2010.

Westall, F. and Southam, G.: The early record of life, Geoph. Monog. Series, 164, 283-304, 2006.

Westall, F., Boni, L., and Guerzoni, E.: The experimental silicification of microorganisms, Palaeontology, 38, 495-528, 1995.

You, Y., Han, J., Chiu, P. C., and Jin, Y.: Removal and inactivation of waterborne viruses using zerovalent iron, Environ. Sci. Technol., 39, 9263-9269, doi:10.1021/es050829j, 2005.

Zillig, W., Kletzin, A., Schleper, C., Holz, I., Janekovic, D., Hain, J., Lanzendörfer, M., and Kristjansoon, J. K.: Screening for Sulfolobales, their plasmids, and their viruses in Icelandic solfataras, Syst. Appl. Microbiol., 16, 609-628, 1994. 